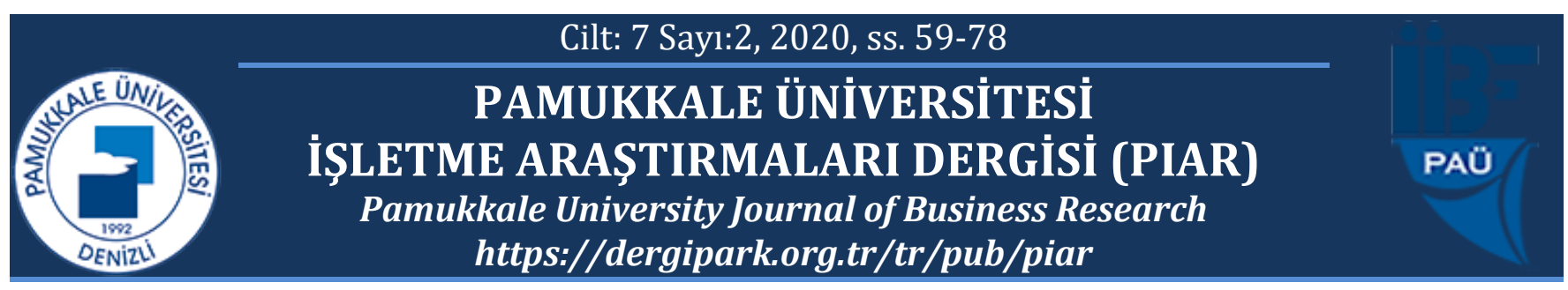

\title{
Yöneticilerde İş Ahlâkı: Kavramsal Bir İnceleme
}

\author{
Business Ethics in Managers: A Conceptual Review
}

\section{Ramazan ERDEM11 $\quad$ Dilruba İZGÜDEN ${ }^{2}$ * Durmuş GÖKKAYA ${ }^{3}$}

\begin{abstract}
${ }_{1}^{1}$ Süleyman Demirel Üniversitesi, IÏBF, Türkiye, razanerdem@sdu.edu.tr, https://orcid.org/0000-0002-5986-8280 ${ }^{2}$ Süleyman Demirel Üniversitesi, İ̈BF, Türkiye, dizguden@hotmail.com https://orcid.org/0000-0002-6938-8854 ${ }^{3}$ Yozgat Bozok Üniversitesi, İ̈BF, Türkiye, durmus.gokkaya@yobu.edu.tr, https://orcid.org/0000-0002-6713-1748

* Yazışılan Yazar/Corresponding author
\end{abstract}

\section{Öz}

Küreselleşmeyle birlikte gelen uluslararası anlaşmalarda yaşanan güven sorunlarl, kut kaynaklar, artan rekabet koşulları, işsizlik, toplumsal baskılar, medyada sık sık gündeme gelen yolsuzluk skandalları ob. faktörler iş ahlâkı kavramının günümüz dünyasındaki önemini daha da ön plana çıkarmıştır. Bu bă̆lamda çalışma kapsamında yöneticiler açısından iş ahlâkı kavramı ele alınmış, Kant'ın ahlâk felsefesi ve literatürdeki diğer çalışmaların ışı̆̆ııda iş ahlâkının evrensel olup olmadığ konusuna değinilmiş ve iş ahlâkının işletmelerin ve toplumların geleceği açısından önemli bir konu olduğ $u$ üzerinde durulmuştur. Ayrıca yöneticilerin iş ahlâkı konusundaki yeri, önemi, sorumlulukları ve astlarla olan ilişkileri ortaya konularak incelenmeye çalışılmıştır. Çalışma literatür incelemesi kapsamında yürütü̈lmüştür. Sonuç olarak, küresel ekonominin ilgilendiği konular arasında yer alan kıt kaynakların doğru bir şekilde kullanılarak sürdürülebilir bir dünya oluşturulması konusunda yöneticilere büyük görevler düşmektedir. Yöneticiler işletmelerin imajının sağlamlaştırılması, topluma karşı olan sosyal sorumluluklar, müşteri memnuniyetinin gözetilmesi, müşteriye ve çalışanlara dürüst davranılması, çalışanların hak ve özgürlüklerinin gözetilmesi ve çalışanlarmın ahlâki değerlere uygun davranmasını sağlanmak noktasında birtakım sorumluluklara sahiptir. Geçmişten günümüze yönetim kuramcıları da bu konulara değinmiş ve çalışma kapsaminda Frederick Taylor, Chester Barnard ve Peter Drucker'ın yönetim kuramlarına kısaca yer verilerek kuramcıların iş ahlâkına ilişkin uygulamalarına değinilmiştir.

Anahtar kelimeler: Ahlâk, İş Ahlâkı, Yöneticiler

JEL kodları: : M10, M19

\begin{abstract}
Confidence problems in international agreements that come with globalization, scarce resources, increasing competition conditions, unemployment, social pressures, corruption scandals that come up frequently in the media, etc. factors have highlighted the importance of the concept of business ethics in today's world. In this context, the concept of business ethics in terms of managers was discussed within the scope of the study, in the light of Kant's moral philosophy and other studies in the literature, the issue of whether business ethics is universal or not, and it was emphasized that business ethics is an important issue for the future of businesses and societies. In addition, the place of managers in business ethics, their importance, responsibilities and their relations with subordinates were revealed and tried to be examined. The study was conducted within the scope of the literature review. As a result, managers have a great responsibility to create a sustainable world by using the scarce resources, which are among the issues of concern to the global economy. Managers have certain responsibilities in terms of strengthening the image of enterprises, social responsibilities towards society, observing customer satisfaction, treating customers and employees honestly, observing the rights and freedoms of employees and ensuring that their employees act in accordance with moral values. Management theorists from the past to the present have also touched upon these issues and within the scope of the study were briefly mentioned the management theories of Frederick Taylor, Chester Barnard and Peter Drucker and were mentioned the practices of theorists regarding business ethics.
\end{abstract}

Keywords: Ethics, Business Ethics, Managers

JEL codes: M10, M19 


\section{GİRiş}

İş dünyasında yaşanan ahlâki sıkıntılar ve bunların giderilmesinin gerekliliği iş ahlâkını üzerinde durulması gereken bir kavram haline getirmiştir. Bu bağlamda iş ahlâkı kavramı 1960'larda akademideki yayınlara girmiş, 1980'lerden sonra da işletmecilik literatüründeki yerini sağlamlaştırmıştır. İşletmelerde kendini gösteren yolsuzluk davaları, adam kayırma, rüşvet, çalışanlara yapılan kötü muameleler, tedbirsizlikten kaynaklanan iş kazaları, haksız elde edilen kazançlar, hatalı ürünleri piyasaya sürme, müşteri memnuniyetini göz ardı etme vb. günümüz dünyasında sık sık gündeme gelmekte ve bunun sonucu olarak da iş ahlâkına ayrı bir önem atfetmek gereği ortaya çıkmaktadır. İş ahlâkı kavramı ahlâk kavramının işletmelerde kendini gösteren biçimi olup çalışanlar, yöneticiler, işletmeler ve toplumlar açısından önem arz etmektedir. Bu bağlamda çalışma kapsamında ilk olarak iş ahlâkı kavramının ne olduğuna ve önemine değinilecektir. Sonrasında kısa bir biçimde Kant'ın ahlâk felsefesi ve bunun iş ahlâkına olan yansımaları ele alınacaktır. Çalışmada iş ahlâkı kavramının işletmeler açısından uygulanabilir olup olmadığı, kavramın evrensel bir nitelik taşıyıp taşımadığı, işletmeler için bir kazanç mı zarar mı olduğu noktasında literatürdeki çalışmalar ışığında bilgilere yer verilecektir.

Bilindiği üzere yöneticiler işletmelerde süreçlerin yönetilmesi noktasında anahtar bir role sahiptir. Buradan yola çıkarak denilebilir ki iş ahlâkı kavramının kurumsallaştırılması ve iş süreçlerine kazandırılması noktasında yöneticilere büyük görevler düşmektedir. İş ahlâkı kavramının işletmelerin hem iç hem de dış müşterileri açısından yani çalışanlar ve toplum açısından önemli olduğu gerekçesi ve aynı zamanda ahlâki unsurların işletmenin imajı üzerindeki etkilerinden ötürü çalışmada yöneticilerin bu konuda neler yapması gerektiği ele alınmıştır. Bu çerçevede yönetim kuramcılarından birkaç isim ve bu isimlerin kuramlarının iş ahlâkı çerçevesinde değerlendirilmesi yapılacak ve iş ahlâkına uygun çalışma ortamları yaratılması noktasında yöneticilerin üstlerine düşen görevler ve küresel ölçekte yöneticilerin iş ahlâkının hangi noktaları açısından kritik olduğu inceleme konusu olacaktır.

\section{2. İŞ AHLÂKI}

İş ahlâkı kavramına geçmeden önce ahlâk kavramının ne olduğuna kısaca değinmekte fayda vardır. Burada belirtmek gerekir ki etik ve ahlâk kavramları birtakım yönlerden birbirinden ayrılmakla birlikte (etik bir ahlâk felsefesi, ahlâk ise etiğin bir çalışma alanı (Yeşil, 2011: 67; Bektaş, 2015: 334)) pek çok çalışmada da olduğu gibi bu çalışma kapsamında da eş anlamlı olarak kullanılmış (Özturan, 2015: 3) ve yararlanılan kaynaklar bu doğrultuda ele alınmıştır. Karışıklık olmaması açısından etik ve ahlâk kavramı ayrı ayrı ele alınmaktan ziyade çalışma kapsamında ahlâk kavramının kullanılması uygun görülmüştür.

Toplumsal bir varlık olan insan bir arada yaşamının bir gereği olarak, davranışlarını düzenleyen, hak ve yükümlülüklerini gösteren birtakım kurallara uymak zorundadır (Bektaş, 2015: 328; ${ }^{1}$ ). Ahlâk kavramı toplumların kültürel normları çerçevesindeki doğru ve yanlışları ve bunlara uygun olarak davranılmasını, bunların toplum içerisinde doğuracağı sonuçların farkında olmayı anlatan toplumun değer yargılarını ortaya koyan ve toplumu bu bağlamda yönlendiren bir kavramdır (Pehlivan, 1998: 8; Şahin ve Demir, 2000: 204; Yeşil, 2011: 66; Bektaş, 2015: 329). "Nasıl yaşamamız gerekir?" sorusunun zamana, mekâna, topluma ve kültüre göre bulduğu cevaplar ahlâk felsefesinin özünü oluşturmaktadır (Pehlivan, 1998: 9; Arslan, 2001: 2). Ahlâk, toplumlarda düzenin sağlanmasına yardımcı olan 
yazılı olmayan kurallardan oluşmaktadır (Stewart, 1996: 7; Pehlivan, 1998: 8). Toplumlarda bireyler kendi istek ve çıkarları doğrultusunda ahlâki değerleri göz ardı ederek yaşamlarını sürdürdüklerinde, toplum içerisinde çatışma ortamları oluşacak, bireyler yalnızlaşacak, toplum düzeninin temelleri sarsılacaktır (Stewart, 1996: 7-9). İnsanlığın geleceği açısından küresel çapta baş gösteren fakirlik, işsizlik, adaletsizlik, çevre kirliliği, hoşgörüsüzlük, şiddet vb. durumlar ahlâki bir çöküntünün göstergelerindendir (Akar, 2008). Ahlâki değerlerin olmadığı yahut göz ardı edildiği toplumlarda yaşanacak olan çıkar çatışmaları, sosyal yapının zarar görmesi vb. hususlar, işletmelerde de kendini gösterebilmektedir. Kâr amacı, rekabet koşulları vb. faktörler doğrultusunda ahlâk unsurunun yok sayıldığı işletmelerde toplumsal anlamda, rakip firmalar ve aynı zamanda işletme içi çalışanlar bağlamında pek çok sıkıntı ortaya çıkabilecektir. Bu nedenledir ki ahlâk kavramı işletmeler açısından da çok önemli bir kavramdır. Bu bağlamda işletmelerde ahlâk kavramının kendini gösterdiği bir biçim olan iş ahlâkı kavramının ne olduğunun ortaya konması gerekmektedir.

İş ahlâkı ile ilgili olarak bilinmesi gereken ilk nokta iş dünyasına ait özel bir ahlâkın olmadığı, ahlâk kavramının alt boyutlarından birini de iş ahlâkı kavramının oluşturduğudur (Arslan, 2001: 5; Zaim, 2009: 127). İş ahlâkının özünde bulunan ahlâk kavramının temelinde bireylerin iyi ve kötü, yanlış ve doğrunun ayrımının farkında olmaları yatmaktadır (Taeusch, 1932: 274; Pehlivan, 1998: 6-8; Jackson, 1996; Şahin ve Demir, 2000: 212). Bahsi geçen neyin iyi neyin kötü olduğu ya da neyin doğru neyin yanlış olduğu ise toplumdan topluma, kültürden kültüre farklılıklar gösterebilmektedir (Taeusch, 1932: 274). İş ahlâkı kavramı genel manasiyla toplumda kabul görmüş ahlâki ilkelerin işletmeler içerisinde kendisini gösteren, uygulamalı bir ahlâk bilgisidir. Anlaşılır ki iş ahlâkı ahlâk bilgisinin uygulamalı halinin temsillerinden birini ortaya koymaktadır (Arslan, 2001: 5; Şahin ve Yıldırım, 2008: 56; Zaim, 2009: 127). İş ahlâkı, iş dünyasının sağladığı imkânlar karşısında bireylerin sağduyulu seçimler yapmalarına yönelik yol gösterici ilke ve değerlerden oluşan bir disiplin türüdür (Özgener, 2008: 35). İşletmelerde de ahlâki uygulamalara önem atfedilmekte ve başkalarının hakkına girilmeden, hırsızlık, yolsuzluk vb. ahlâk dışı olaylardan uzak bir biçimde işletmelerin faaliyetlerini yerine getirmesinin gerektiği ifade edilmektedir (Akar, 2008: 1112).

Amerikan kültürünün de temellerini oluşturan "sana yapılmasını istemediğin bir şeyi başkasına yapma" cümlesi ahlâki değerlerin temeline atıfta bulunmaktadır. Bunu iş dünyası bağlamında düşündüğümüzde biz bir ortağımızı, şirketi ya da genel manasıyla iş ortamındaki bir başkasını kandırdığımızda, aldattığımızda onun da bize bu türden ahlâk dışı davranışlarda bulunabileceğini göz ardı etmememiz gerekmektedir (Bowie, 1999: 11). Bu nedenledir ki iş ahlâkı kavramı küreselleşen dünyada işletmelerin karşılıklı güven ilişkileri geliştirerek anlaşmalar yoluna gidebilmesi noktasında önemli bir faktördür.

İş ahlâkında işletmedeki çalışanlar arasında, çalışanlar ile yöneticiler arasında, işletme ile diş müşteriler arasında, işletme ile diğer sosyal faktörler arasında vb. ortaya çıkabilecek olan ahlâki sorunlar inceleme konusu olarak ele alınmaktadır (Arslan, 2001: 5). İş ahlâkı kavramının temelinde işletmelerin faaliyetlerinin bireyler ve toplum açısından ahlâki anlamda kabul edilebilir olması gerekliliği yatmaktadır (Manufisa, 200: 248). Bu bağlamda işletmeler faaliyetlerini yürütürken bulundukları toplumun ahlâki değerlerini de göz önüne almalıdırlar (Şahin ve Yıldırım, 2008: 56). İşletmeler faaliyetlerini yerine getirirken dış ve iç çevrelerine karşı sorumlulukları bulunmaktadır (Aktan, 2004). Belirtilen bu 
sorumluluklardan sosyal sorumluluklar işletmelerin diş çevreyle ilişkisini ilgilendiren unsurlardan oluşmakla birlikte, iş ahlâkı ise işletmelerin hem iç hem de diş çevreye karşı olan sorumluluklarını içine alan daha kapsayıcı bir kavramdır (Şahin ve Demir, 2000: 204). İşletmelerin kendi çalışanlarına, pay sahiplerine, ortaklarına vb. (iç çevre) ve devlete, topluma, doğaya vb. (dış çevre) karşı sorumlulukları bulunmakta ve faaliyetlerini yerine getirirken bunları göz önüne almaları gereklilik önem arz etmektedir (Aktan, 2004). İş ahlâkına uygun faaliyetler göstermeyen işletmeler toplum tarafından tepkiyle karşılanarak tüketicilerin satın alma davranışlarını etkileyecek ve pazar paylarında kayıplar yaşayabilecek (Nalbant, 2005: 193; Torlak, 2009: 110) ve bunların yanı sıra işletme içerisinde de çalışanlarının güven kaybını yaşayarak, işletmenin amaçlarına ulaşması noktasında da sıkıntıya düşebilecektir. Bununla birlikte nitekim "çalışanların veya yöneticilerin iş ahlakı ilkelerine uygun hareket etmemesi yüzünden işletmeler maddi ve manevi açıdan zarara uğramaktadır. Söz konusu zararlar "ölçülebilen" ve "ölçülemeyen" zararlar olarak iki grupta ele alınabilir. Ölçülebilen zararlar işletmelerin, iş ahlakı ile ilgili çeşitli ihmal ve suiistimallerden ötürü ödemek zorunda kaldıkları tazminatlar, cezalar veya bu sebeple maruz kaldıkları iş gücü/verimlilik kayıpları gibi hususlardır. Ölçülemeyen zararlar ise bahsi geçen suiistimallerin sebep olduğu güven ve itibar kaybı gibi, sonuçları daha uzun süre etkisini devam ettiren ve tamiri güç olan hususlardır. Nitekim "Güven bir ruh gibidir, bir kere gittiğinde bir daha geri gelmez." sözü bu durumu veciz biçimde ifade etmektedir" (Çelik, 2010: 39).

Kurumların temel amaçlarından biri kâr maksimizasyonunun sağlanmasıdır. Kurumlar bu amaç doğrultusunda etik değerleri ikinci plana atarak, tüketici haklarını ihlal etme, kayıt dişı ekonomilere yönelme, ürün kalitesini ve müşteri memnuniyetini göz ardı etme, çalışan haklarını önemsememe, çevreye zarar verme, rüşvet-yolsuzluğa başvurma, yasal yükümlülükleri ve ahlâki değerleri göz ardı etme vb. uygulamalarda bulunabilmektedir (Arslan, 2001: 6; İlhan, 2005: 259; Şahin ve Yıldırım, 2008: 56). Ek olarak, işletmelerin müşterilerin istek ve ihtiyaçlarını göz ardı ederek daha çok kâr getiren ürünlere yönelmesi, ürünlerle ilgili araştırma sonuçlarına dair yanıltıcı bilgilerin kamuoyuna sunulması, hedeflere ulaşılmış gibi gösterilmek amacıyla yılsonu rakamlarıyla oynanması, tedarikçi şirket seçiminde informal yollarla sağlanan hediyelerin kabul edilmesi gibi tutumlar da iş ahlâkına aykırı düşmektedir (Tierney, 1997: 20). İşletmelerde kuralları (işletme içerisinde mevcut olan ya da işletmenin bulunduğu sektöre has kuralları) ihlal etmek, art niyetli davranışlar sergilemek (yöneticiler, çalışanlar tarafından), rekabet koşullarında adil olmayan uygulamalara gitmek de iş ahlâkına uygun düşmeyen hareketler içerisinde yerini almaktadır (Bowie, 1999: 16-19). Bunların yanı sıra küreselleşmenin getirilerinden olan rekabet unsuru, bireysel çıkarların ön planda olması, insani değerlere verilen önemin azalması vb. ahlâki değerlerin işletmelerde hem çalışanlar hem de yöneticiler tarafından görevlerini yerine getirme noktasında göz ardı edilme noktasına gelebildiği görülmektedir (Zaim, 2009: 126). Küreselleşmenin diğer getirilerinden biri olan işletmelerin hızla büyüme tutkusu kıt kaynakların bilinçsizce kullanılarak kentleşme sorunu ve çevre kirliliği gibi sorunlara yol açmıştır (Özgener, 2008: 36). İşletme içerisinde çalışanlar arasında ayrımcılık yapılması, işe alım süreçlerinde siyasi- dini vb. görüşlerin ön planda olması, adam kayırma, çalışanlar üzerinde baskı kurarak yıldırma-korkutma politikalarının uygulanması, yasal ihlaller, emek sömürüsü, çalışanların yararını gözetmeme, görev ve yetkilerin kötüye kullanımı gibi 
durumlar da iş ahlâkına aykırı unsurlar olarak işletmelerde görülebilmektedir (Pehlivan, 1998: 71-79). Bu tür olaylar da bizlere iş yaşamındaki ahlâki boşlukların varlığını görülür kılmaktadır (İlhan, 2005: 259; Şahin ve Yıldırım, 2008: 56; Zaim, 2009: 126). İşletmelerde yaşanan bu olaylar yöneticiler, çalışanlar ve toplum genelinde olumsuz geri dönütlere yol açabilmektedir. Arslan (2001: 6)'nın da belirttiği üzere, iş ahlâkı kavramının ortaya çıkış nedeni bu tür olayların yaşanmaması ve işletmelerdeki ahlâki duyarlılığın arttırılması ihtiyacıdır. Özgener (2008: 48)'in çalışmasında ifade ettiği gibi, sürdürülebilir bir gelecek için iş ahlâkı önemli bir faktördür. Dünya üzerindeki herkes düşünülerek kaynak dağıtımı yapılmalı ve ahlâki değerler bu şekilde yönlendirici olmalıdır.

Dünya nüfusu bilindiği üzere giderek artmakta ve bunun bir sonucu olarak da işsizlik kavramı kendini göstermektedir. İşsizliğin artmasıyla birlikte yoksullukla birlikte çalışanlar arasında da rekabet artacak ve çıkarlar doğrultusunda bireyler birbirine zarar vermeye başlayabilecektir. Bunun yanı sıra günümüz dünyasının sorunları, artan çevre kirliliği ve bunun sonucunda çevresel sürdürülebilirliğin sağlanması ihtiyacı da iş ahlâkı kavramının gerekliliğini öne çıkarmaktadır (Arslan, 2001: 10-11). İş ahlâkı kurumlarda istikrarın sağlanması açısından önemli bir unsurdur. Bunun nedeni iş ahlâkının rüşvet, adam kayırma, yolsuzluk vb. yanlışları engelleyici bir özelliğe sahip olmasındandır (İlhan, 2005: 258). İş ahlâkının işletmelerde uygulanması ile birlikte işletmeler birbirlerine ve işletme içerisinde de çalışanlar kendi aralarında ve yöneticilerine karşı daha çok güven duygusu besleyebilecek ve daha rahat işbirlikleri yapabilecektir. Yanı sıra, çalışanlar işletmelerde daha insani koşullarda çalışabilecek ve çalışma performansları da artış gösterebilecektir. İşletmeler iş ahlâkına uygun davrandığında hem kendi içlerinde hem diğer şirketlerle hem de içinde bulundukları toplumla daha uyumlu hale gelebilecek ve zorlukları aşması da kolaylaşacaktır. Aksi takdirde, iş ahlâkına aykırı davranan işletmeler bu durum ortaya çıtığında sektörde ve toplumda büyük bir güven kaybı yaşayabilecek ve kurum imajı ciddi anlamda zedelenebilecektir. Ek olarak işletme içerisinde de bir güvensizlik ortamı oluşabilecek ve kurum içi iletişim zarar görerek, çalışanların örgüte olan bağlılıkları da bu durumdan olumsuz yönde etkilenebilecektir (Tierney, 1997: 30-65).

1960-1970'lerde üniversitelerde ve pek çok farklı alanda iş ahlâkı kavramı ile ilgili yazılar ve tartışmalar ele alınmıştır. Bununla birlikte, 1970'lerin sonu ve 1980'lerin başında, bugün bildiğimiz iş ahlâkı kavramı kurumsal ilerlemeler kaydetmiş ve 1980'lerin sonundan itibaren işletmecilik literatüründeki yeri giderek önemli bir hal almaya başlamıştır (Arslan, 2001: 1; Abend, 2008: 411). İş ahlâkı kavramı çerçevesinde yerli ve yabancı literatürde çeşitli sayıda ve konuda kitaplar, çalışmalar yapılmış; 1982 yılında "Journal of Business Ethics", 1991 yılında "Business Ethics Quarterly" vb. iş ahlâkına ilişkin dergiler yayın hayatına girmeye başlamıştır (Abend, 2008: 411). 2008 yılında ise "İş Ahlakı Dergisi Türkçe" literatürde konuyla ilgili olarak yerini almıştır. 1980 yılında "The Society for Business Ethics"2, 2003 yılındaysa "Türkiye İktisadi Girişim ve İş Ahlakı Derneği" kurulmuştur³. Aynı zamanda Türkiye'de 2016 yılında ilki gerçekleştirilmiş olan Türkiye İş Ahlakı Zirvesi'de her yıl düzenlenen bir organizasyon olarak iş ahlâkının önemine vurgu yapılmaktadır ${ }^{4}$. Bunların yanı sıra Türkiye'de ve Dünya'da konuyla ilgili olarak pek çok çalışma yapılmış, konuya ilişkin kitaplar kaleme alınmış, akademilerde bu konuyla ilgili verilen derslere olan ilgi artmış ve işletmeler içerisinde de yönetici ve çalışanlara bu konuyla ilgili eğitimler verilmiş ve verilmeye devam etmektedir. 
Bu kapsamda Eğri ve Sunar (2010) “Türkiye'de iş ahlakı çalışmaları: mevcut durum ve yönelimler" adlı çalışmalarında son dönemde Türkiye'deki iş ahlakı alanında yaşanan gelişmeleri ve yönelimleri ele almıştır. Yapılan bu uygulamalı saha çalışmasında Türkiye' deki iş ahlakı çalışmaları kamu sektörü, özel sektör ve sivil toplum kuruluşları ve ek olarak üniversiteler açısından incelenmiştir. Çalışmaya göre; "kamuda iş ahlakı ile ilgili çalışmalar doğal olarak yasal düzenlemeler ile yürütülmektedir. Özel sektördeki gelişmeler firmaların pazar arayışları ve artan rekabet ile paralel gitmektedir. Firmalar kurumsal ilişkiler ve markalaşma açısından temel bir araç olarak gördükleri iş ahlakı uygulamalarını kamuoyunda güveni tesis etmek için kullanmaktadırlar. İş ahlakı alanında sivil toplum kuruluşlarının yaptığı çalışmalar ise daha çok çeşitli uygulamalar üretme ve iş ahlakını özendirmeye odaklanmaktadır. Öte yanda, akademik alanda yapılan araştırmalar da benzer şekilde olgudan çok uygulamaya, teorik olmaktan ziyade vakaya yöneliktir. Üniversitelerdeki ahlak eğitimi de genellikle soyut ve felsefi alanla sınırlı kalmakta ve güncel sorunlarla ilgili bir bakış üretememektedir.".

Diğer yandan Arslan (2001: 14) Türkçe literatürde iş ahlâkı konusuyla ilgili yayınlamış olduğu ve bu konuyla ilgili yapılan diğer çalışmalara 1şık tutan "İş ve Meslek Ahlakı" başlıklı kitabında dağıtıcı adalet kavramının iş ahlâkı açısından önemine değinmiş ve bu bağlamda öğretim üyelerinden yurtdışında önemli dergilerde makaleleri yayınlanan, kongrelere katılan, bildiriler hazırlayan, kitaplar yazan öğretim üyeleriyle bu konularda bir çaba harcamayan öğretim üyelerinin aynı maaşı aldığından ve bu nedenden ötürü araştırma yapmanın çekiciliğinin kalmadığından bahsetmiştir. Söylemek gerekir ki günümüzde akademik örgütlerde 18.12.2015 tarihinde yayınlanan Akademik Teşvik Ödeneği Yönetmeliği ile bu durum değişmiş ve artık öğretim üyelerine çalışmaları sonucu hesaplanan akademik teşvik puanları doğrultusunda maaşlarına ek ödemeler yapılmaktadır. Fakat akademik teşvik puanının gündeme gelmesiyle birlikte akademik çalışmalar temel amaçlarından saparak para kazanma aracı olarak görülmeye başlanmış ve birtakım kongreler odak noktalarını akademik katkıdan ziyade ticari çıkarlara doğru kaydırarak niteliklerini düşürmüşlerdir, yanı sıra yine dergilerde yayın yapma konularında informal ilişkiler daha da önem kazanarak yıl dolmadan makale yayınlatma çabaları akademisyenlerin ortaya koydukları çalışmaların da niteliklerinde düşüşlere yol açmakla birlikte dergilerin de kalitelerini sorgulanır hale getirmiştir. Bu konuyla ilgili olarak YÖK tarafından 09.01.2018-E.2191 tarih ve sayılı "Akademik Teşvik Ödeneği Başvuruları" konulu evrakta bu konuya değinilerek, inceleme komisyonlarında bu konulara dikkat edilmesinin gerekliliği vurgulanmıştır. Sonuç olarak iş ahlâkı gerçek anlamda hassas bir konudur ve aslında bakılırsa uygulamalar bireyleri iş yerlerinde her ne kadar ahlâklı davranmaya itse de kişilerin vicdanları iş ahlâkı konusunda ön plana çıkmaktadır. Çalışanlar işlerini yaparken ahlâki kuralları kendi vicdan muhasebelerinden geçirerek yaparlarsa, örneğin bir öğretim görevlisi araştırmalarını para kazanmaktan ziyade çalıştığı alana bir katkı yapmak amacıyla yapar ise iş ahlâkına uygun bir davranış sergilemiş olabilecektir. Bu şekilde çalışanlar hem kendilerine, hem çalıştıkları kuruma, hem de ülkelerine daha yararlı olabilecektir.

\section{KANTIN AHLÂK FELSEFESİ KAPSAMINDA İŞ AHLÂKI: İŞ AHLÂKI EVRENSEL Mi?}

Alman filozof İmmanuel Kant ahlâk kavramını kişisel çıkarlardan tamamen ayrı tutan bir düşünce yapısına sahiptir. Bu ahlâk feslefesi çerçevesinde, ahlâki olma durumu koşullara 
bağlı olmaksızın her koşulda ortaya konması gereken davranışlar bütününü temsil etmektedir. Kant ahlâkiliği böyle tanımlayarak saf bir ahlâk kuramı ortaya koymaya çalışmıştır. Kant ahlâkının temelinde akıl ve vicdan yasaları yer almaktadır (Arslan, 2001: 1213). Kant'ın ahlâk kuramına göre her birey ahlâki değerlere sahiptir. Buradan yola çıkarak bireylerden oluşan işletmeler de ahlâki değerlere sahip olacaktır (Bowie, 1999: 82-83). İş ahlâkını Kantçı ahlâk perspektifinden ele alacak olursak, işletmeler kendi faydalarından ziyade toplumun faydasını gözeterek ahlâklı uygulamalara gitmelidirler. Örnek vermek gerekirse, işletmelerin çalışanlarına yönelik sağladıkları iş güvenliği sistemleri, çalışma ortamlarının iyileştirilmesi vb. uygulamalar işletmenin kendi faydasından ziyade çalışanlarının yaşama haklarına saygıları gereği yaptıkları uygulamalar olduğunda iş ahlâkına uygun olmuş olacaklardır (Arslan, 2001: 14).

Kant'ın ahlâk anlayışı doğrultusunda bakıldığında iş ahlâkı ilkeleri evrensel geçerliliğe sahiptir (Bowie, 1999: 14-15). İş ahlâkı ilkeleri de koşullara, durumlara bağlı olmaksızın geçerlilik göstermektedir. Küreselleşmeyle birlikte gelen ahlâki sıkıntıların artış göstermesi küresel çapta geçerlilik gösteren ahlâki değerlerin olmasını gerekli kılmıştır (Arslan, 2001: 14). Kant'ın ahlâk anlayışı çerçevesinde bakıldığında iş ahlâkı kapsamında uyulması gereken bazı evrensel ilkeler şu şekilde belirtilebilecektir (Bowie, 1999: 90-91; Arslan, 2001: 15):

- İşletmeler aldıkları kararlarda bu karardan etkilenebilecek olan bütün paydaşlarını göz önüne almalıdır.

- İşletmeler alacakları kararları ve uygulamaya sokacakları politikaları bunlardan etkilenebilecek olan gruplara bu politika ve kararlar uygulamaya konulmadan önce benimsetilmelidir.

- Yolsuzluk, rüşvet, adam kayırmacılık vb. uygulamalardan kaçınılmalıdır.

- Bir paydaşın çıkarı diğer paydaşın zararı olacak durumlarda zarara uğrayabilecek olan paydaşın hakkı gözetilmelidir.

- Paydaşlar aldatmamalı ve haklarına saygı gösterilmelidir.

- Çevreye zarar verilmemelidir.

- İşletme içerisinde uygulamalarda doğruluk, dürüstlük, adalet ilkelerinden sapılmamalıdır.

Kant'ın ahlâk felsefesine göre iş ahlâkı evrensel nitelikler taşımakla birlikte, Zhang ve diğerleri (2007: 176) çalışmasında iş ahlâkının evrensel olamayacağını ifade etmiştir. Bahsi geçen çalışmada ve benzer şekilde Clarke ve Aram (1997: 562-563)'ın yapmış oldukları çalışmada iş ahlâkının pek çok unsurunun farklı kültürlerde farklı biçimlerde kendini gösterebileceğine değinilmiştir. Zhang ve diğerleri (2007: 176) iş ahlâkının işletmenin bulunduğu toplum, kültür, coğrafi yerleşim yeri, sosyokültürel değişkenler, tarihi gelişmeler ve bireysel farklılıklara göre değişebileceği belirtilmiştir. Konuyla ilgili olarak, Akar (2008: 11-12)'ın çalışmasında belirttiği üzere İslam dini ahlâki değerlerin toplumun her alanında korunup yaşatılması hususuna son derece önem veren bir dindir. İslam inancinda mutluluğun ahlâklı davranmakla geleceği düşünülmekteyken, Batı kültüründe ise daha çok hazların peşinde koşulması yoluyla bunun sağlanacağı düşünülebilmektedir (Joshanloo, 2013). Güney (2006: 140)'İn çalışmasında vermiş olduğu, Japonya'da iş ilişkisi olan birey ya da şirketlerin birbirlerine pahalı hediyeler vermesinin hoş karşılanırken, Amerika'da ise bu 
durumun rüşvet şeklinde algılanacağı ve ahlâki kabul edilmeyeceği, örneği de bahsi geçen konunun örneklerinden sayılabilmektedir. Vogel (1992) de konuyla ilgili yapmış olduğu çalışmada, iş ahlâkının tam manasıyla küresel bir niteliğe sahip olmadığını belirtmiştir. Özellikle kapitalist yapıdaki toplumlarda yöneticilerin gündeme oturan skandallarıyla birlikte hem akademide, hem iş dünyasında hem de kültürel bağlamda iş ahlâkı konusunun daha da göze çarpar bir hale geldiği belirtilmiştir. Bu bağlamda Vogel çalışmasında Amerika'nın iş ahlâkında Avrupa ülkeleri ve Japonya'dan farklılaştığını ifade etmiş ve Amerika'da ahlâki kararların bireyi ve yasaları, Avrupa ülkelerinde ise toplumu ve informal yolları sosyal kontrol bağlamında esas aldığını belirtmiştir. Clarke ve Aram (1997: 569-570) örneklerde belirtilen farklılaşmanın işletme içerisindeki çalışanların iş ahlâkına aykırı olarak sergiledikleri davranışların altında yatan nedenler boyutunda da farklılıklar gösterdiğini ortaya koymuştur.

\section{YÖNETICIILER AÇISINDAN İŞ AHLAKI}

Yöneticilikle ilgili pek çok tanımlama yapılmış ve bu tanımlamalarda "iyi yönetici" kavramı öne çıkmıştır. Geçmişte yapılan yönetici tanımlarında daha çok başarı ve etkililik üzerinde durulmakla birlikte Platon bunlardan farklı olarak yöneticilerin ahlaki değerleri üzerinde yoğunlaşmıştır. Günümüzde iyi yönetici denildiğinde akla ahlâki açıdan ve teknik açıdan yeterli ve etkili yöneticiler gelmektedir. Yöneticilerin hem etkili bir yönetim ortaya koyması hem de ahlâki değerlere uygun davranması gerekmekle birlikte, yöneticiler genellikle kâr hedeflerini insani değerlerin önüne koyarak, ahlâk unsurunu ikinci plana atabilmektedirler. Eğer ki bir yönetici çalışanlarının güvenliği, çevrenin korunması vb. konuları kâr maksimizasyonu amacının önüne geçirebilirse ahlâk faktörünü esas almış olacaktır. Tarihsel bağlamda bakıldığında da ahlâk unsurunu ön plana koyan yöneticilerin başarısız olabilecekleri yönünde bir algının mevcut olduğu söylenebilecektir (Ciulla, 2002: 340-341). Amerika Birleşik Devletleri'nde 1977-1981 yıllarında başkanlık yapmış olan Jimmy Carter insan unsurunu gözeten, çevreyi ve kaynakları koruyucu politikalar ortaya koyan bir başkan olmakla birlikte, başkanlık dönemi boyunca yaşanan krizler, enflasyon oranlarındaki dalgalanmalar vb. faktörlerden dolayı etkisiz ve başarısız bir başkan olarak görülmüştür (Hargrove, 1999: 1-12; Ciulla, 2002: 341). Burada görülür ki ahlâk unsuru ve etkililik unsuru iyi yöneticilik anlayışını farklı yönlerde etkilemektedir. Ciulla (2002: 341) bu konuyu çalışmasında "the Hitler problem (Hitler sorunu)" şeklinde ele almıştır. Burada sorulması gereken "Hitler iyi bir lider (yönetici) midir?" sorusudur. Etkililik bağlamında bakıldığında Hitlerin kitleleri kararları doğrultusunda nasıl yönlendirdiği tarihsel süreçte bariz bir şekilde görülmektedir. İyi yönetici kavramı bireyleri etkilemek ve görevlerin yerine getirilmesini sağlamak çerçevesinde ele alınacak olursa Hitler'in iyi bir yönetici olduğunu söyleyebiliriz. Peki ya ahlâki unsurlar? Hitler' in Yahudi soykırımı, insanlara yaptığı türlü işkenceler hiçbir şekilde bir yöneticinin yapmaması gereken, ahlâka kesinlikle sığmayan faktörlerdendir. Buradan anlaşılacaktır ki, iyi yöneticinin sadece bireyleri amaçlar doğrultusunda etkilemesi yetmemekte aynı zamanda bunu gerçekleştirirken ahlâki değerlere bağlı kalması ve hatta bu ahlâki değerleri çevresindeki bireylere de yansitarak onların da bu şekilde davranmasını sağlaması gerekmektedir. Tierney (1997: 30) ve Baron (2009: 15)'un da belirttiği üzere önemli olan, ahlâki değerlerin geliştirilmesinin, işletmenin başarısını engelleyecek yahut tehdit edecek bir faktör olarak değil, işletmenin çalışma yöntem ve standartlarını iyileştirecek bir fırsat olarak görülmesidir. Güney (2006: 144)'in de ifade ettiği üzere işletmeler toplumsal 
fayda gözeterek, azınlıklar konusunda yardımlarda bulunma, çevreye yönelik yatırımlar yapma, kadınlara ve engellilere istihdam alanı oluşturma vb. faaliyetlerin işletmenin kârını düşüreceğine inanmakta ve bu nedenle bu tür uygulamalardan uzak durmaktadırlar. Fakat bu tür uygulamalardan uzak duran işletmeler kısa vadede yüksek kârlar elde etseler bile uzun dönemde bulundukları toplumun tepkisiyle karşılaşabilecek ve satışlarında düşüşle birlikte maliyetlerinde artışla karşılaşabileceklerdir. Özgener (2008: 48)'de çalışmasında küresel krizlerin altında yatan nedenlerden birinin toplumlardaki ahlâki yönetici eksikliği olduğunu belirtmiş ve toplumların ihtiyaçlarını göz ardı etmeyen, olaylara bütüncül bakış açısıyla yaklaşan, iş ahlâkına önem veren yöneticilerin küresel çaptaki gerekliliğine vurgu yapmiştır.

Yöneticiler astlarını ya da çalışanlarını bir "üretim aracı" olarak görmek yerine onları öncelikle bir insan olarak görmeleri gerekmektedir. Böylelikle yöneticinin bu bakış açısına sahip olması astlarla ilişki kurmasında ve onları yönlendirmede büyük kolaylık sağlayacaktır. Bunun yanında astlardan veya çalışanlardan eksiksiz, zamanında ve doğru bilgi gelmesini sağlayacak karşılıklı güvene dayalı bir ortam oluşturmaktan, astların alınan kararlara kolaylıkla katılmasını sağlamak, onları motive etmek, astlarla iletişim kurma, liderlik yapma, planlama, kontrol ve koordinasyon gibi yönetim fonksiyonlarını yerine getirmeye kadar yönetimin özünü oluşturan faaliyetler, yönetici ile astlar arasında arasındaki ilişkilerin kapsamını meydana getirmektedir (Koçel, 2015: 592). Bu ilişkiler yumağı iş ahlakı zeminine ne kadar oturtulursa örgütün ya da işletmenin amaçlarına ulaşması da o derece kolay olacağı açıktır. Yöneticinin iş ahlakı tutumu ve davranış kalıpları, merkezi ya da kilit bir rol oynayarak bu başarının sağlanmasında önemli bir etkiye sahip olduğu söylenilebilir.

İş ahlâkına uygun olarak davranan yöneticiler diğer yöneticilerden ayrılmaktadır. Yöneticilerin asıl amacı işletmede faaliyetlerin aksamadan yürümesini sağlamak ve bunu yaparken kârı maksimum seviyede tutmaktır. Aynı zamanda bu tarz yöneticiler bu faaliyetlerini devlet müdahalesi doğrultusunda yasalara uygun olarak gerçekleştirmek zorunluluğu taşımakta, bunun haricinde toplumsal manada bir sorumluluk üstlenmemektedirler. Fakat iş ahlâkına uygun davranan yöneticiler ahlâki yönetimin öneminin farkında olarak zorunluluklarının yanı sıra ahlâk unsurunu faaliyetlerin merkezine koymaktadırlar. Ahlâki yönetimi benimseyen yöneticiler faaliyetleri sonucu karbondioksit oranındaki artış, ormanların tahribatı vb. çevresel zararların toplum açısından etkilerini de gözeterek faaliyetlerini yerine getirmektedir. Ahlâki yönetimi benimseyen işletmeler faaliyetlerindeki toplumsal dışsallığı göz önüne alır ve bunu gönüllü olarak yerine getirirler (Baron, 2009: 13-15). Ek olarak yöneticiler karar verirlerken topluma karş1 sorumluluklarını da düşünmek durumundadırlar. Yöneticiler şu durumu merkezlerine oturtmalıdırlar. Ahlak kuralları yol haritaları gibidir, yararlı ve vazgeçilmez. Ancak arazinin yapısına göre sürekli olarak dikkat göstererek özenli olarak kullanılması gereken yol göstericileridir (Demir ve Songür, 1999: 150).

Kişisel çıkarlarını işletmenin ve toplumun çıkarlarının önüne koymak, haksız kâr elde etmek, vergi gibi yasal yükümlülüklerde devleti yanıltarak bu tür sorumluluklardan kaçmak, işe alma ve terfi sistemlerinde adil davranmamak, çalışanların insani ve hukuki haklarına saygı göstermemek, şirket sırlarını paylaşmak, bilgiyi yanlış kullanmak, çalışanlar arasında düşmanlık veya güvensizlik gibi olumsuz duygular yaratmak vb. davranışlar yöneticiler 
tarafından sergilenebilmekte olan iş ahlâkına aykırı davranışlar arasında yer almaktadır (Güney, 2006: 135). Yöneticiler çalışanlarının ahlâki davranışlar sergilemelerini sağlamak amacıyla öncelikli olarak kurum kültürüne ahlâki ilkeleri yerleştirmeli ve çalışanlara bu doğrultuda sergiledikleri davranışlar çerçevesinde rol model olmalıdırlar. Yani, iş ahlâkı bağlamında yöneticilere düşen ilk görev önce bireysel ahlâkları konusunda özenli olmak ve sonrasında bunu çalışanlarına aksettirmektir (Stewart, 1996: 212-213; Mafunisa, 2000: 248249; Güney, 2006: 135-136). Bununla birlikte çalışanlarını iş ahlâkına uygun davranışlar sergilemeleri konusunda motive ederek ve bu davranışlar sonucunda çalışanları ödüllendirerek çalışanların iş ahlâkına uygun davranışlar sergilemesini sağlamak, çalışanlara iş ahlâkı konusunda eğitimlerin verilmesi, yöneticilerin iş ahlâkı konusunda üzerine düşen görevler arasında yer almaktadır (Stewart, 1996: 212-213; Mafunisa, 2000: 248-249). Çalışanlar ve toplumdaki bireyler yöneticilerden doğru nedenlerle, doğru şeyleri, doğru zamanda yapmasını beklemektedir (Ciulla, 2002: 341). İş ahlâkı küreselleşen dünya ile birlikte daha da gerekli hale gelmiştir. Küreselleşmeyle birlikte çok uluslu işletmelerde farklı kültürden, farklı ahlâki değerlere sahip bireyler bir arada çalışması gerekli olacak ve bu bireyler arasında ayrım yapılmadan, kendi aralarında saygı çerçevesinde çalışmalarının sağlanması gerekmektedir (Arslan, 2001: 10-11; Özgener, 2008: 37). İş ahlâkının sağlandığı iş ortamlarının oluşmasında yöneticilere büyük görevler düşmektedir. Yöneticiler işletmelerinde uygulanmak üzere ahlâki standartlar ortaya koymalıdırlar (Tierney, 1997: 27).

Yöneticiler aldıkları her kararda ahlâk unsurunu gözetmeli ve işletme içerisinde meydana gelen ahlâki sorunlara da çözüm aramalıdırlar (Şahin ve Demir, 2000: 204). Bowie (1999: 9091) çalışmasında ahlâki işletmelerin (iş ahlâkına uygun işletmelerin) bir takım aldıkları kararlarda paydaşlarının (iç ve dış paydaşlar) da etkilenebileceğini düşünerek bu minvalde kararlarını ve politikalarını düzenlemelerinin gerektiğini belirtmiştir. Özgener (2008: 38)'in de ifade ettiği üzere işletmeler sosyal faydalarını arttırmak ve iş ahlâkına uygun hareket edebilmek açısından tüm paydaşlarının çıkarlarını düşünmeli ve bunları dengeleme konusunda özen göstermelidir. Şahin ve Demir (2000: 205) yöneticilerin karar alırken; hangi yasaların seçilerek uygulanmasının gerektiği, yasalardaki ekonomik ve sosyal konuları ve hangi durumlarda bireysel çıkarların işletme çıkarlarının önüne geçeceği konularını göz önüne almalarının gerektiğini vurgulamıştır.

Diğer taraftan yönetici ve çalışanlar ya da astlar arasında en önemli ilişkilerden biri de yöneticinin gücü ya da otoritesini kullanma konusudur (Koçel, 2015: 592). Yönetici iş ahlakı gereği elinde bulundurduğu bu yetkiyi bütün astlarına eşit bir şekilde kullanması gerekmektedir. Aksi yönde bir tutum ve davranışa sahip olursa çalışanlar arası huzursuzluk ve memnuniyetsizlik meydana getireceği açıktır. Ayrıca yöneticilerin dürüst ve güvenilir olması iş ahlakı açısından önemlidir. Whitener vd., (1998: 516)'nin belirtiğine göre çalışanlar, yöneticilerin sözleri ve eylemleri arasındaki tutarlılığı gözlemler ve onların doğruluğu, dürüstlüğü ve ahlaki karakteriyle ilgili çıkarımlarda bulunurlar. Çalışanların yöneticilerine olan güvenini etkileyen özellikler olarak; "doğruyu söylemek ve verilen sözleri tutmak" şeklinde belirtilmiştir. Bu kavramlar çalışanların yöneticileri hakkında bulundukları dürüstlük çıkarımlarının temel davranış öncülleri olarak görülmektedir. Buradan yöneticilerin davranışlarındaki tutarlığı gören astlar onlara karşı güven duyarak ve inanarak daha motivasyonlu çalışacağı çıkarımında bulunabilir. Bu çıkarımı destekleyen Connell vd., (2003) yaptıkları çalışmada yönetici-ast ilişkilerinde güven faktörünün ne kadar önemli 
olduğunu ve yöneticilerin ya da liderin rolünün altı çizilmiştir. Connell vd., (2003: 570-571) "güvenin var olma derecesi", organizasyon yapısı, kontrol mekanizmaları, iş tasarımı, iletişim, iş tatmini, bağlılık ve örgütsel vatandaşlık davranışı gibi faktörleri etkileyerek bir organizasyonun karakterinin çoğunu belirleyebildiğini ifade etmektedir. Aynı zamanda, "güvenin" öncelikle bir kuruluşun yöneticileri aracılığıyla tesis edildiğini belirtmektedir. Bunun yanında güven ve yönetime ilişkin literatürde, güvenin, liderlerin ya da yöneticilerin astları ile olan ilişkilerinde merkezi bir özellik olduğunu göstermektedir. Bu kapsamda, bir organizasyonunun karakterinin iş ahlakı çerçevesinde şekillenmesi işletmenin liderinin ya da yöneticisinin astlar ile arasındaki güven ilişkisinin pozitif yönlü sağlanmasından geçtiğini söylemek mümkündür.

Yöneticiler iş ahlâkının işletmelerde uygulanmasında önemli roller üstlenmektedirler. Çalışanların hak ve özgürlüklerine saygı gösterilmesi, sigortalarının yapılması, maaşları (emeklerinin karşılığının verilmesi) konusunda gerekli özenin gösterilmesi, çalışma ortamlarında rahatlığın ve güvenliğin sağlanması vb. faktörler yöneticilerin işletmelerde uygulaması gereken ahlâki görevleri arasında yer almaktadır (Pehlivan, 1998: 69-70; Akar, 2008: 20-23). Ek olarak, yöneticiler kurum içerisinde alınacak olan kararlara çalışanlarının da katılımını sağlamalı ve alınacak olan bu kararların çalışanlar tarafından da benimsenmesine özen göstermelidir (Bowie, 1999: 96). Böylece yöneticiler bu uygulama yoluyla hem kendileri iş ahlâkına uygun davranmış olacak hem de alınan kararlar çalışanlar tarafından da kabul görebileceğinden ve kararların uygulama aşamasında çalışanlar iş ahlâkının gereklerini yerine getirme konusunda daha istekli olacaklardır. Tierney (1997: 30)'in de çalışmasında belirttiği üzere iş yaşamındaki ahlâki değerler yöneticiler açısından tehdit ya da sıkıntı olarak algılanmaktan ziyade çalışma yöntemlerinin iyileşmesini sağlayan fırsatlar olarak görülmelidir. Diğer yandan Zaim (2013: 194)'e göre “iş hayatında erdemli insanın özelliklerini inceleyen geniş ve kapsamlı bir araştırmada çalışanların ve yöneticilerin temel ahlaki ve mesleki yetkinlikleri tespit edilmeye çalışılmıştır. Çalışma sonucunda dikkat çeken hususların başında "dürüstlük" ilkesi hem yöneticiler hem de çalışanlar açısından en önemli ahlaki yetkinlik olarak görülmüştür. Çalışanlar açısından dürüstlükten sonra en önemli görülen ahlaki kriterler arasında "çalışkanlık", "iş ahlakına sahip olma" ve "güvenilirlik" gelirken, yöneticiler için diğer ikisi aynı olmakla birlikte "çalışkanlık" kriterinin yerini "adil olma" kriteri almıştır". Bu çalışmada görüldüğü üzere iş ahlakına hem çalışanlar hem de yöneticiler düzeyinde sahip olmanın bir yolu da erdemli insan olmaktan geçtiği söylenebilir.

Çalışanlarının takım ruhunu destekleyen, onların hakkını gözeten, çalışanlar arasında adaleti sağlayan, çalışanlarının sosyal ihtiyaçlarını da göz önüne alan yöneticiler iş ahlâkına uygun olan bu davranışlarının karşılığını işletmelerinde göreceklerdir. Çalışanlar yöneticilerinin iş ahlâkına uygun bu tarzdaki davranışları sonucunda kurumlarına daha çok bağlanabilecek, motivasyonları artabilecek ve aynı zamanda yöneticilerine olan güvenleri de artacağından iş ahlâkına uygun davranan yöneticilerin çalışanlarına iş yaptırmaları da daha kolay olabilecektir (Bowie, 1999: 82). İş ahlâkına sahip çalışanların örgütlerine olan bağlılıkları daha yüksek, işlerini severek yapma, işlerini yaparken verimli ve etkili olma isteği, güvenilir olma, kaliteli ürünlerin ortaya çıkması için çaba harcama, işe gelmeme oranlarının düşük olması vb. eğilimlerin daha sık görüldüğü söylenebilmektedir (Mafunisa, 2000: 248). Bu kapsamda Çelik' in (2010: 21) "iş ahlakı uygulamalarının çalışan memnuniyeti ile ilişkisi" adlı çalışmasında "iş ahlakına, işletmelerde ahlaki yönetim ve çalışan memnuniyetine teorik 
olarak değinilmiş ve İstanbul ilinde faaliyet gösteren bir katılım bankasında çalışanlar üzerinde yapılan bir anket çalışması ile iş ahlakı ve çalışan memnuniyeti arasındaki ilişki incelenmiştir. $\mathrm{Bu}$ araştırma sonuçlarına göre iş ahlakı uygulamalarının çalışan memnuniyetini arttırdığı" görülmüştür.

İşletme içerisinde iş ahlâkının kurumsallaştırılması yöneticilerin görevleri arasında yer almaktadır (Demir ve Songür, 1999: 165; Şahin ve Demir, 2000: 212). Yönetimin belirlediği kurallar, ahlâk komiteleri, yasal kurallar, ahlâk eğitim programları, şikâyet büroları, yazılı ahlâk kuralları ve bu konuyla ilgili politika ve prosedürlerin ortaya konması iş ahlâkını kurumsallaşma yolları arasında yer almaktadır (Demir ve Songür, 1999: 164; Özgener, 2008: 41). Yöneticiler çalışanlarını ahlâki olarak hem kendi davranışlarıyla hem de bu konuyla ilgili düzenleyecekleri eğitimler doğrultusunda yönlendirebileceklerdir (McDonald, 2000: 171).

Tierney (1997: 73-90) ahlâki değerlere uygun bir çalışma ortamının oluşturulması konusunda yöneticiler tarafından yapılabilecekleri şu şekilde sıralamıştır:

- Yöneticiler ahlâki değerlere bağlı kalma konusunda hassasiyet göstermelidirler. Yöneticiler ahlâki değerlerin önemini kabul ederek, iş ahlâkının gereklerini daima öncül planda tutmalı, ikinci plana atmamalıdırlar.

- Yönetici olmanın getirilerinden olan 'diğerlerini etkileme' faktörünün farkında olunması gerekmektedir. Yöneticiler çalışanlarını davranış, değer ve tutumları doğrultusunda etkilemekte ve onlara örnek olmaktadır. Bu nedenle yöneticiler iş ahlâkına uygun kararlar almalı, bu doğrultuda uygulamalara gitmelidir ki, çalışanlar da bunu görerek iş ahlâkına uygun davransın. Yöneticilerin bu bağlamda iş ahlâkına yönelik işletmelerinde koyduğu kurallar kadar kendilerinin sergilemiş oldukları davranışlar ve gözettikleri değerler de çalışanlar tarafından gözlemlenerek örnek alınabilecektir (Tierney, 1997: 75-81; Demir ve Songür, 1999: 165).

- Yöneticilerin iş ahlâkına uygun davranış sergilenmesi gerekliliğinin işletme çalışanlarına benimsetilmesini sağlaması gerekmektedir. Ahlâki değerlerin kurum içerisinde yaygınlaşması ve benimsenmesi noktasında yöneticiler sorumluluk almalıdırlar. $\mathrm{Bu}$ minvalde daha önce de belirtildiği üzere yöneticiler birtakım kurallarla bunu sağlamakla birlikte kendi davranış ve değerleri yoluyla da çalışanlarına bunu göstermelidirler.

- İş ahlâkına uygun davranışların neler olduğunun yönetici tarafından belirlenmesi gerekmektedir. Yöneticilerin işletmelerinde ahlâki olarak kabul edilebilir ya da edilemez davranışların neler olduğunu ortaya koyması gerekmektedir. İşe alma süreçleri, muhasebe işlemleri, ürün tasarımı, rakiplere yönelik stratejiler vb. pek çok konuda işletme neyi ahlâka uygun bulacak, neyi ahlâka uygun bulmayacak konularında yöneticiler bir çerçeve oluşturmalıdırlar.

- İşletmenin ahlâki değerlerinin neler olduğunun açıkça belirtilmesi gerekmektedir. Yöneticiler koydukları ahlâki standartları çalışanlarına karşı açıkça belirterek nasıl davranmaları gerektiği konusunda çalışanlarını aydınlatmalıdırlar.

- Çalışanların iş ahlâkı konularında eğitilmesi gerekmektedir. Yöneticilerin çalışanlarına işlerini yaparken hangi ahlâki değerleri gözetmeleri gerektiğine dair toplantılar yapması gerekmektedir. 
- İşletme içerisinde açı iletişimin desteklenmesi gerekmektedir. Yöneticiler ahlâki değerlere uygun iş ortamları oluşturabilmek için açık iletişimden yana olarak gerçeklere duyarlı olmalıdırlar. Kassing (1997: 48)'in ifade ettiği üzere işletmelerde yönetici çalışan arasındaki iletişim kanalları açık olduğunda, çalışanlar kurum içerisinde gördükleri sorun, sıkıntı ve aksaklıkları yöneticilerine karşı dile getirme konusunda daha istekli olabilecektir. Tierney (1997: 90)'in de çalışmasında geçtiği üzere çalışanların gördükleri bu tür olumsuzlukları yöneticilere karşı dile getirmesi ahlâki açıdan da büyük önem taşımaktadır. Bu yolla yöneticiler işletmelerindeki ahlâk dışı uygulamaların ayrımına daha kolay varabilecek ve bu sorunlara çözüm bulma yoluna gidebilecektir. Bu bağlamda Kassing (2011: 128-129)'in de söylediği gibi bu tür davranışlar çalışanların örgütte yaşadığı sorunlara, ahlâk dışı davranışlara yönelik önemli geri dönütler sağlanmasına yardımcı olacak ve işletmenin iyileştirme süreçleri için de önemli katkılara yol açacaktır.

- İş ahlâkıyla ilgili konularda bir tutarlılık sergilenmesi gerekmektedir.

Yöneticiler yukarıda belirtilenlerin yanı sıra işletmelerinde hak dağıtımında eşitlik, adaletsizlikleri cezalandırma, görev, sorumluluk ve yararların dağıtımında adalet sağlama, dürüstlük ve doğruluk ilkelerinin benimsetilmesini sağlama, çalışanlarına karşı tarafsız bir tutum sergileme, çalışanların insan hakları konusunda duyarlı olma, çalışanlarının örgütsel bağlılıklarının artması yönünde çalışmalarda bulunma, işletme içerisinde hukukun üstünlüğü ilkesinin ön planda tutulması, faaliyetleri yürütürken yasal çerçevelerin dişına çıkılmaması konusunda hassasiyet gösterilmesi, farklı din, kültür, etnik yapılardan gelen çalışanlara hoşgörüyle yaklaşılması konularında iş ahlâkına uygun bir şekilde davranmaları gerekmektedir (Pehlivan, 1998: 57-64). Yöneticilerin bu hususlara dikkat etmesi işletmenin geneli açısından büyük önem arz etmektedir. Yöneticilerin özellikle de üst yönetimin iş ahlâkına aykırı bir davranışı işletmenin tamamının imajının sarsılmasına yol açabilecektir (Özgener, 2008: 43).

Baron (2009: 15) çalışmasında yöneticilerin iş ahlâkına uygun davranmasının işletmenin itibarı açısından son derece önemli olduğunu vurgulamıştır. İçinde bulunduğumuz yüzyılın getirilerinden olan medyanın her alana nüfuz etmiş olması, tüketici grupları, sivil toplum örgütlerinin yaygınlaşmış ve etkili olması iş ahlâkını da etkileyen faktörler arasında yer almaktadır (Ciulla, 2002: 344-345). Diğer yandan Tekin vd., (2018: 144)'nin yaptığ1 çalışmada "kadın girişimcilere yarı yapılandırılmış görüşme yöntemiyle; "işletmelerinin kuruluşu ve yürütülmesi sürecinde iş ahlâkı ve sosyal sorumluluk yaklaşımları" hakkında düşünceleri sorulmuştur. Kadın girişimciler; girişimciliğin, tüm toplumun hatta tüm dünyanın düzeninin sağlanmasında önem taşıdığını, ayrıca iş ahlâkının girişimci ve işletmelerin itibar ve marka değerleri için önemli bir gösterge olduğunu, sosyal sorumluluk bilincinin çevreye ve insanlara zararı en aza indirebileceği görüşüne sahiptirler. Kadın girişimciler aslında girişimcilik tanımı ile iş ahlâkı ve sosyal sorumluluk uygulamalarının ayrılmaz bir bütün olduğunu ifade etmişlerdir. Ancak katılımcılar, her geçen gün ahlâki sorunların artmakta olduğunu, kâr elde etmeyi ön plana alan girişimciler nedeniyle güvenilir olmayan ürünlerin üretildiği, çevreye zarar verildiği, kıt kaynakların bencilce kullanıldığını da belirtmişlerdir"." Günümüzde işletmelerin yasa dışı uygulamalara gitmesi, kimyasal atıklarını denizlere dökmesi, müşterilere hatalı ürün satması vb. durumlar medya araçları sayesinde büyük yankı bulabilmekte ve işletmenin imajını olumsuz bir şekilde etkileyebilmektedir. Şahin ve Demir (2000: 204)'in de çalışmalarında ifade ettiği gibi, televizyon, internet vb. popüler yayın 
organlarında iş hayatında yaşanan skandallara yer verilmekte, hapishaneye ya da mahkemeye gönderilen iş adamları, firma yetkilileri bu mecralardan duyurulmaktadır.

Bunlara ek olarak, bu tür olaylar yaşandığında tüketici grupları, sivil toplum örgütleri vb. topluluklar işletmeye karşı cephe almakta ve bu işletmenin satışlarını ve dolayısıyla kârını düşürebilmektedir. Ek olarak, çağın getirisi olan teknolojik gelişmeler, bilgiye erişimin kolaylaşması tüketicilerin yani müşterilerin bilinçlenmesini sağlamakta ve bu da işletmelerin ahlâk dışı uygulamalarının, müşteriyi kandırmaya, yanıltmaya yönelik uygulamalarının daha kolay fark edilmesine yol açmaktadır. Müşteriler ve çalışanlar dışında uluslararası anlaşma yoluna gidebilecek olan işletmeler karşı taraftaki işletme ile ilgili bilgileri rahatlıkla elde edebilecektir. Bu nedenden dolayı işletmeler faaliyetlerini yürütürken iş ahlâkı kuralları gereği şeffaflık ilkesini edinmeli ve güven konusunda işletmeyi sıkıntıya düşürecek ahlâk dışı uygulamalardan kaçınmalıdır.

Clarke ve Aram (1997: 562-563) yapmış oldukları çalışmada, daha önce de belirtildiği üzere iş ahlâkının farklı kültürlerde farklı biçimlerde kendini gösterebildiğini belirtmiştir. Yöneticiler de işletmelerinde iş ahlâkı unsurlarını yapılandırırken bulundukları toplumun kültürel özelliklerinden etkilenmektedirler. Vogel (1992) çalışmasında Amerikalı yöneticilerin diğer kapitalist ülkelere ve Avrupa ülkelerine nazaran iş ahlâkına ilişkin konularda daha duyarlı olduğunu ifade etmiştir. Yukarıda da değinildiği üzere Vogel Amerikalıların ve buna bağlı olarak Amerikalı yöneticilerin iş ahlâkı konusunda daha çok bireysel faktörleri esas aldığını, Avrupalı yöneticilerin ise daha çok toplumsal faktörleri esas aldığını belirtmiştir. Anlaşılmaktadır ki, iş ahlâkının kültürel, coğrafi ve toplumsal boyutlarda göstermiş olduğu değişim yöneticiler ve bu yöneticilerin işletmelerinde uygulamaya koydukları iş ahlâkı standartları üzerinde de kendisini göstermektedir. Ancak diğer taraftan bakıldığında kapitalizmin başkenti sayılan Amerika'da her şey tüketime odaklı olduğundan bazen amaca ulaşmak için her şeyin mubah sayılması anlayışı olan makyevelist düşünce sistemlere ve kişilere hâkim olabilmektedir. Böylelikle ahlak ve özelliklede iş ahlakı ikinci planda kalabilmektedir. Bunun yanında yine sosyalist sistemlerde benzer durumlar söz konusu olabilir. Özetle batı dünyasında görünenin yanında bir de görünmeyen yönlerden bakıldığında böyle bir durumlarla karşılaşılabilir. Bu kapsamda iş ahlakı sadece batı dünyasında yoktur. Doğu toplumlarında özellikle İslam coğrafyasında da bu anlayış, hassasiyet ve bakış açısı gelişmiştir. Burada insan faktörü önemlidir. Dürüst, adil ve güvenilir bir kişi her ortamda ve zamanda ahlak kavramına önem verecek ve bunun da işine yansitacaktır.

Schwartz (2007) konuyla ilgili olarak yapmış olduğu "The Business Ethics of Management Theory" başlıklı çalışmasında yönetim kuramları ve iş ahlâkı arasındaki ilişkinin incelenmesine yönelik çalışmaların yetersiz olduğuna değinmiş ve bu bağlamında üç yönetim kuramcisı (Frederick Taylor, Chester Barnard ve Peter Drucker) üzerinden bu konuyla ilgili bilgilere yer vermiştir. Schwart buradan yola çıkarak üç yönetim kuramcısı ve bunların iş ahlâkına olan yaklaşımlarını şu şekilde ifade etmiştir:

- Frederick Taylor: İlk büyük yönetim kuramcısı olarak kabul edilen Taylor "Bilimsel Yönetim İlkeleri" başlıklı kitabıyla bilindiği üzere bilimsel yönetim yaklaşımının temellerini ortaya koymuştur (Schwartz, 2007: 44; Koçel, 2015: 237). Taylor yönetsel kuraminda rasyonelliği ön planda tutarak, iş süreçlerine standartlar getirmiş ve çalışanların kontrolünün 
sağlaması konusunu vurgulamıştır (Schwartz, 2007: 45; Koçel, 2015: 240-241). Taylor'un bilimsel yönetim yaklaşımına getirilen eleştirilerin temelinde insan faktörünün göz ardı edilmesi hususu yatmaktadır. Yönetimdeki bu yaklaşım türü Kant'ın ahlâk felsefesine aykırı bir durumu temsil etmektedir. Taylor bu eleştirilere cevap mahiyetinde yönetim kuraminda uygulama ve metod-yöntem bağlamlarında çalışanlarının katılımının desteklenmesini sağlamıştır. Taylor yöneticiler tarafından küçümsenen çalışanların düşüncelerini, fikirlerini ve gördükleri yanlışlıkları dile getirmeme eğiliminde olduğunu belirtmektedir. Bu nedenden dolayı da Taylor yöneticilerin çalışanlarını işletme içinde yahut dışında gördükleri yanlışları dile getirmesi konusunda cesaretlendirici olmaları gerektiğini ifade etmiştir. Taylor'un yönetim kuramı iş ahlâkına aykırı birtakım durumları içerisinde barındırmasına rağmen günümüzde halen geçerliliği olan bir kuramdır (Schwartz, 2007: 45-46). Taylor çalışmalarında net ve belirgin bir biçimde iş ahlâkı kavramına değinmemekle birlikte çalışan memnuniyeti, çalışan hakları, katılım vb. öğeler Taylor'un yönetim uygulamalarından olup, iş ahlâkının da birtakım öğelerini içerisinde barındırmaktadır (Schwartz, 2007: 45).

- Chester Barnard: Barnard çalışmalarında formal organizasyon yapılarının yanı sıra bu yapılarda yer alan insan faktörünün göz ardı edilmemesi gerektiğini vurgulamıştır. Barnard çalışanların motivasyonlarını sağlayan bireysel amaçlarının, isteklerinin olduğunu kabul etmiş ve bunların yöneticilerin teşvik ve tutumları yoluyla işletmelerin amaç ve hedeflerine uygun olarak yönlendirebileceğini belirtmiştir. Çalışanların amaçlarıyla organizasyonun amaçları birbiri ile uyumlaştırıldığında organizasyonlar etkililiği yakalayabilmektedir. Barnard'ın bu yaklaşımı iş yerindeki ahlâki sorunların gündeme gelmesinde etkili olan faktörlerden olmuştur. Barnard 1938 yılında "The Functions of The Executive" başlıklı bir kitap yayınlamıştır. Bu çalışmasında yöneticinin sorumluluklarını ve bu çerçevede bireylerin ahlâki davranışlarının kökenlerini, sosyal çevreleri (ekonomik, dini, politik..), teknolojik uygulamaları eğitim ve öğretim bağlamlarında tanımlar. Ahlâki değerlerin bireylerin istek ve arzularının doğrultusunda davranış sergilemeleri noktasında bir kontrol görevi gördügüunü ifade etmiştir. Bununla birlikte Barnard bu çalışmasında iş ahlâkı konusunda yöneticilerin üzerine düşen görevlerden de bahsetmiştir. Çalışmada iş ahlâkı ile ilgili olarak yöneticilerin işletmelerinde iş ahlâkı kodları oluşturmalarının, iş süreçlerinde bunlara bağlılık göstermelerinin ve bunların çalışanlar tarafından da benimsetilmesinin gerektiği ifade edilmiştir (Schwartz, 2007: 46-47). Barnard (1958)'ın konuyla ilgili olarak “Elementary Conditions of Business Morals" başlıklı çalışmasında ise iş yerinde sergilenen davranışlar konusunda ahlâki davranışların yöneticiler tarafından ne derece motive edildiği, konuyla ilgili iş yerinde yaşanan çatışmalar ve bunların çözüm yollarına değinilmiştir. Barnard çalışanların organizasyonun amaçları doğrultusunda yönlendirilmesi gerektiğini söylemekle birlikte bu durum sağlanırken insan doğasına saygılı davranılması gerektiğini de belirtmektedir. Buradan Barnard'ın yönetsel yaklaşımının Kant'ın ahlâk felsefesine daha yakın olduğu söylenebilecektir (Schwartz, 2007: 47).

- Peter Drucker: Drucker yönetim kuramlarına 'desantrilizasyon' ve 'hedefler doğrultusunda yönetim' kavramlarının kazandırılmasında önemli rol oynamıştır. Drucker'ın yönetim kuramlarına olan bu katkıları iş ahlâkı boyutunda da yansımalar göstermiştir. Desantrilizasyonla birlikte özerk olan yöneticilerin ahlâki değerleri güven unsuru açısından ön plana çıkmıştır. Drucker'in bir diğer öğretisi olan hedefler doğrultusunda yönetim yaklaşımı sonucunda ise yöneticilerin işletme kârını maksimum seviyeye çıkarma uğruna iş 
ahlâkına aykırı davranışlar sergileyebilmesi de söz konusu olmuştur. Ek olarak Drucker sonrasında iş ahlâkı konularına girecek olan kurumsal sosyal sorumlulukla ilgili de çalışmalarda bulunmuştur. Çalışmalarında yöneticilerin aldıkları kararların toplum üzerinde de etkili olduğunu ifade etmiştir. Drucker iş ahlâkını tanımlarken bireylerin vicdan muhasebesi vurgusu yerine yöneticilerin iş ahlâkı konusundaki uygulamaları ve işletmelerin karşılıklı ilişkilerinde ahlâka uygun davranması (bireysel olarak ahlâka uygunluktan ziyade bu şekilde davranılması iki tarafın da yararına olacağından) durumunu vurgulamıştır (Schwartz, 2007: 47-51).

Buraya kadar olan bölüm özetlenecek olursa, "yöneticinin iş yapma aracı psiko-sosyal bir varlık olan "insandır". Yöneticilik işinin özü, insan çalıştırmak, insanlarla beraber çalışmak, çalışma ekibini oluşturan insanların (astların, grup ve takım üyelerinin, işletme personelinin) örgütsel hedefler doğrultusunda istekli bir şekilde çalışmalarını; bilgi yetenek ve becerilerini tam olarak bu doğrultuda harcamalarını sağlamaktır. Yönetici, insanı insan yapan tüm özellikleri, genetik, psikolojik, sonradan edinilmiş, geçici veya kalıcı alışkanlıkları, kendine has karekteri ve dünya görüşü olan, zaman içerisinde her özelliği itibarıyla değişen vb. özellikleri bünyesinde taşıyan bir "çalışma aracı" (insan) ile organizasyon amaçlarına ulaşmaya çalışmaktadır. Hepsi birbirinden farklı özellik taşıyan insanları bir ekip halinde ve isteyerek verilen hedefler doğrultusunda çalıştırmak, bu insanlarla birlikte hedeflere ulaşmaya çalışmak, günlük dilde insan çalıştırmak olarak adlandırılan olay bir yönetici için en büyük zorluktur" (Koçel, 2015: 729). Yöneticiler, örgütler ya da işletmelerde, çalışanların bireysel rolleri ile örgütün rolleri ya da amaç ve hedefleri arasında merkezi bir konumda bulunmaktadır. Bu bağlamda yöneticilerin işletmelerde koordinasyon sağlaması ve etkili kararlar vererek astları ve örgütü uyumlu bir şekilde çalıştırması iş ahlakı çizgisinden geçtiği açıça ifade edilebilir. Yöneticilerin dürüstlüğü, sorumluluk sahibi olması, güven veren bir yapısının olması, otorite yetkisini ya da elinde bulundurduğu gücü adil bir şekilde kullanması ve söyledikleri ile davranışlarının tutarlı olması bütün paydaşları (astlar ya da çalışanları, işletmenin hedeflerini ve yöneticinin kendisini) iş ahlakı çerçevesinde memnun edeceği açıktır. Bu kapsamda iş ahlakının organizasyonda hâkim anlayış haline gelmesinde yöneticilere önemli görevler düşmektedir.

\section{SONUÇ}

Çalışma kapsamında öncelikli olarak ahlâk kavramına kısaca değinilmiş ve sonrasında da iş ahlâkı kavramı ele alınmıştır. İş ahlâkı kavramının ahlâkın alt boyutlarından biri olduğu belirtilmiştir. Günümüz dünyasının sorunları arasında yer alan rüşvet, yolsuzluk, işe alım süreçlerinde yapılan hilekârlıklar, müşterileri kandırma ve memnuniyetsizliklerini göz ardı etme, şirket anlaşmalarında hilelere başvurma, işletmenin finansal tablolarında oynamalar yapma vb. çeşitli ahlâk dışı uygulamalar iş ahlâkı kavramının konuları arasında yer almakta ve bu nedenle yukarıda da belirtildiği üzere kavramın önemini arttırmaktadır.

Çalışmada belirtildiği üzere iş ahlâkının işletmelerin kârlılığını düşürdüğü ve olumsuz sonuçlara yol açtığı doğrultusunda bazı düşünceler vardır. İşletmelerin kısa vadede durumları ele alındığında ahlâki değerlerin iş süreçlerinde olumlu bir etkisi görülmese bile uzun vadede olumlu etkileri kendini gösterecektir. İşletmelerin devletin koymuş olduğu yasalara uygun davranması ve yanı sıra sosyal sorumlulukları da gözeterek yol alması işletmenin ahlâki değerlere uygunluğunu arttıracak ve hem çalışanlar açısından hem 
yöneticiler açısından hem de toplum açısından olumlu sonuçlar ortaya koyacaktır. İş ahlâkına uygun işleyen işletmeler sosyal sorumluluklara önem vereceğinden topluma katkı sağlamış olacaktır. Bunun işletme için bir yansıması olarak da işletmenin imajı bu tür faaliyetlerden olumlu yönde etkilenecek ve sosyal sorumluluk projelerine önem veren işletmelere müşteriler daha çok güven duyacak ve daha çok bu işletmelerden alişveriş yapabilecektir. Bununla birlikte iş ahlâkına uygun davranan işletmeler küresel pazarda da saygınlık kazanarak karşılıklı güven ilişkileri içerisinde uluslararası anlaşmalar yapabilecektir.

Yöneticiler açısından fayda kısmına gelindiğinde, çalışmanın temelini oluşturan iş ahlâkındaki yönetici faktörü önemli bir konumda durmaktadır. Bu bağlamda çalışmada belirtildiği üzere iş ahlâkının bir işletmede işler hale getirilmesi konusunda yöneticilere büyük görevler düşmektedir. Yöneticiler işletmelerinde birtakım ahlâki kodlar geliştirerek bunları çalışanlarına benimsetmelidirler. Bu minvalde de yöneticilerin öncelikli olarak kendilerinin ahlâki değerlere uygun olarak davranmaları gerekmektedir. Bahsi geçtiği üzere gelişen teknoloji ve medya organları sayesinde yöneticilerin sergilemiş oldukları ahlâk dışı davranışlar gündeme büyük yankılarla düşmekte ve işletmenin genelini olumsuz yönde etkileyebilmektedir. Bu nedenledir ki yöneticilerin işletmede iş ahlâkına uygun davranması, bu konuda çalışanlarına örnek olması, çalışanlarının da bu tür davranışlara uygun davranması yolunda ödül ve ceza sistemleri geliştirmesi ve bu konularla ilgili olarak çalışanlarına eğitimler sağlaması gerekmektedir. İş ahlâkını işletme süreçlerine entegre eden yöneticiler çalışanlarının haklarını gözettiğinden, onlarında kararlara katılımını sağladığından çalışanları tarafından da takdir görecek ve çalışanları işletmenin amaç ve hedefleri konusunda yönlendirmesi kolaylaşacaktır. Aynı zamanda bu yolla çalışanların örgüte olan bağlılıkları artacak ve iş tatmin seviyeleri de yükselecektir.

Ayrıca çalışmada Kant'ın ahlâk felsefesine kısa bir şekilde değinilerek, iş ahlâkının evrensel bir nitelik taşıyıp taşımadığı konusunda Kant'ın ve diğer farklı yazarların görüşleri ortaya konmuştur. Bu bağlamda Kant iş ahlâkının genel geçer olduğunu yani evrensel unsurlar içerdiğini ifade etmekteyse de birtakım genel geçer ahlâki kurallar olmakla birlikte, ülkeden ülkeye, toplumdan topluma, kültürden kültüre değişen ahlâki değerlerinde mevcut olduğu görülmüş ve bunların iş ahlâkında da yansımalarının olduğu dile getirilmiştir. Aynı zamanda toplumlar arasındaki bu farklılaşma toplumlarda bulunan işletmelerin yöneticilerini de etkileyerek bu işletmelerde yöneticilerin iş ahlâkına karşı tutumlarını ve bu minvalde geliştirdikleri iş ahlâkı kurallarını da etkilemektedir.

Ek olarak çalışma kapsaminda Frederick Taylor, Chester Barnard ve Peter Drucker'ın yönetim kuramlarına kısaca değinilerek kuramcıların iş ahlâkına ilişkin uygulamaları ele alınmıştır. Bu çerçevede bakıldığında; Taylor'un bilimsel yönetim yaklaşımı insan unsurunu göz ardı ederek formal örgütlenmeleri ele aldığından iş ahlâkı konularına çok fazla değinmemekle birlikte, Barnard yayınları ile iş ahlâkı konusu üzerine eğilmiş ve Kant'ın ahlâk felsefesine yakın bir tutum benimsemiştir. Drucker ise Kant'ın vicdan muhasebesi olgusunun biraz daha dışına çıkarak, iş ahlâkının karşılıklı yarar bağlamında önemli olduğuna değinmiştir.

Çalışmanın genelinden de anlaşılmaktadır ki iş ahlâkı kavramı geçmişten beri çalışılan bir kavram olmakla birlikte günümüzde önemini sürdürmekte hatta artan bir öneme sahip 
olmaktadır. Küresel ekonominin ilgilendiği konular arasında yer alan sürdürülebilir bir dünya oluşturma konusunda yöneticilere büyük görevler düşmektedir. İş ahlâkı kavramının öneminin bu denli artması, işletmelerin başında bulunan ve işletmelere iş ahlâkını kazandırma konusunda görevli olan yöneticilerin bu konunun üzerine yoğunlaşmasını ve bu konuyla ilgili çalışmalar yapmasını gerekli kılmaktadır. Bu bağlamda çalışmada iş ahlâkının işletmelerin ve toplumların geleceği açısından mühim bir konu olduğu dile getirilmiş ve yöneticilerin iş ahlâkı konusundaki yeri, önemi ve sorumlulukları ortaya konularak bu alana dikkat çekilmiştir.

\section{KAYNAKÇA}

Abend, G. (2008). A Genealogy of Business Ethics. Doctoral Dissertation. Field of Sociology. Northwestern University, USA.

Akar, M. (2008). İş ve Ticaret Ahlakı. Diyanet İşleri Başkanlığı, Grup Matbaacılık.

Aktan, C. C. (2004). Ahlak ve Sosyal Sorumluluk Kavram. http://www.canaktan.org/dinahlak/ahlak/meslek-ahlaki/is-ahlaki-kavram.htm, Erişim Tarihi: 27.10.2017.

Arslan, M. (2001). İş ve Meslek Ahlakı, Ankara: Nobel Yayın Dağıtım.

Barnard, C. I. (1958). “Elementary Conditions of Business Morals", California Management Review, 1(1): 1-13.

Baron, D. P. (2009). “A Positive Theory of Moral Management, Social Pressure, and Corporate Social Performance", Journal of Economics and Management Strategy, 18(1): 743.

Bektaş, Ç. (2015). "İşletmelerde İş Ahlakı. Business and Management Studies", An International Journal, 3(3): 327-363.

Bowie, N. E. (1999). Business Ethics: A Kantian Perspective. USA. Cambridge University Press, Blackwell Publishers.

Ciulla, J. B. (2002). Trust and the Future of Leadership, Norman E. Bowie (Ed.), (ss. 334-349), The Blackwell Guide to Business Ethics, First Edition, Blackwell Publishers.

Clarke, R. \& Aram, J.. (1997). "Universal Values, Behavioral Ethics and Entrepreneurship", Journal of Business Ethics, 16(5): 561-572.

Connell, J, Ferres, N. \& Travaglione, T. (2003). “Engendering Trust in Manager - Subordinate Relationships Predictors and Outcomes", Personnel Review, (32)5: 569-587.

Çelik, S. (2010). “İş Ahlakı Uygulamalarının Çalışan Memnuniyeti İle İlişkisi”, İş Ahlakı Dergisi, 3(5): 21-40.

Demir, M. H. ve Songür, N. (1999). "Sosyal Sorumluluk ve iş Ahlakı", Balıkesir Üniversitesi SBE Dergisi, 2(3): 150-168.

Eğri, T. ve Sunar, L. (2010). “Türkiye'de İş Ahlakı Çalışmaları: Mevcut Durum Ve Yönelimler", İş Ahlakı Dergisi, 3(5), 41-67. 
Güney, S. (2006). “Ahlaki Liderliğin Kavramsallaştırılması ve Ahlaki Yönetimde Liderliğin Rolü. Yönetim ve Ekonomi", Celal Bayar Üniversitesi İktisadi ve İdari Bilimler Fakültesi Dergisi, 13(1): 135-148.

Hargrove, E. C.(1999). Jimmy Carter As President: Leadership and The Politics of The Public Good. LSU Press.

İlhan, S. (2005). “İş Ahlakı: Kuramsal Bir Yaklaşım”, Sosyal Bilimler Dergisi, 258-275.

Jackson, J. C.. (1996). An Introduction to Business Ethics, Oxford: Blackwell.

Joshanloo, M. (2013). "A Comparison of Western and Islamic Conceptions of Happiness", Journal of Happiness Studies, 14(6): 1857-1874.

Kassing, J. W. (1997). Development and Validation of the Organizational Dissent Scale. Doctoral Dissertation. Ohio. ABD: Kent State University.

Kassing, J. W. (2011). Dissent in Organizations, United States: Polity Press.

Koçel, T. (2015). Isşletme Yöneticiliği, İstanbul: Beta Yayınları.

Kurtuluş, B. (2005). “İş ahlakı: Geçmişte ve Günümüzde”, Sosyal Siyaset Konferansları Dergisi, (50): 737-759.

Mafunisa, M. J. (2000). “Positive Work Ethic: A Multi-Cultural Perspective”, Journal of Public Administration, 35(4): 247-260.

McDonald, G. (2000). "Business Ethics: Practical Proposals for Organisations", Journal of Business Ethics, 25(2): 169-184.

Nalbant, Z. E.. (2005). “İşletmelerde Sosyal Sorumluluk ve İş Ahlakı”, Celal Bayar Üniversitesi İ̈BF Yönetim ve Ekonomi, 12 (2): 193-201.

Östuran, H. (2015). Ahlâk Felsefesinin Temel Problemleri, Ankara: Nobel Yayın

Özgener, Ş. (2008). “İş Ahlakının Kurumsallaşmasında Üst Yönetim Kademesinin Rolü”, İş Ahlakı Dergisi, 1(1): 31-54.

Pehlivan, İ. (1998). Yönetsel Mesleki ve Örgütsel Etik, Ankara: Pegem Yayıncılık.

Schwartz, M. (2007). "The “Business Ethics” of Management Theory", Journal of Management History, 13(1): 43-54.

Stewart, D. (1996). Business Ethics. Singapore: Mcgraw-Hill Companies.

Şahin, A. ve Demir, M. H. (2000). “Yönetici İkilemi, İş Ahlakı”, Muğla Üniversitesi SBE Dergisi, 1(1): 203-213.

Şahin, L. ve Yıldırım, K. (2008). “İşletmelerde İş Ahlakı Uygulamaları İçin Genel Çerçeve”, İ̧̧ Ahlakı Dergisi, 1(1): 55-66.

Taeusch, C. F. (1932). “Business Ethics”, International Journal of Ethics, 42(3): 273-288.

İlter, B., Tekin, M. ve Soba, M. (2018). “Girişimcilikte İş Ahlâkı Ve Sosyal Sorumluluk Algısı: Afikad Örneği", Sosyal Ekonomik Araştırmalar Dergisi, 18(36), 131-146. 
Tierney, E. P. (1997). İş Ahlakı Yöneticiler İçin Bir Rehber. Çeviri: Günhan Günay, İstanbul: Rota yayınları.

Torlak, Ö. (2009). “Modern Dünyada Yeşil Pazarlama Ne İfade Ediyor?”, MÜSİAD Çerçeve Dergisi, 49: 108-112.

Vogel, D. (1992). "The Globalization of Business Ethics: Why America Remains Distinctive", California Management Review (Fall), 30-49.

Whitener, E. M., Brodt, S. E., Korsgaard, M. A. \& Werner, J. M. (1998). “Managers as Initiators of Trust: An Exchange Relationship Framework for Understanding Managerial Trustworthy Behavior", Academy of Management Review, 23(3): 513-530.

Yeşil, S. (2011) Uluslarası İş Etiği ve Yönetimi. Ankara: Adalet Yayınevi.

Zaim, H. (2009). “İş Ahlakı”, MÜSİAD Çerçeve Dergisi, (49): 126-129.

Zaim, H. (2013). “İş Hayatında Erdemli İnsanın Yetkinlikleri İle Performans Arasındaki İlişki", İstanbul Ticaret Üniversitesi Sosyal Bilimleri Dergisi 12(23): 181-196.

Zhang, Y., Straub, C. \& Kusyk, S.. (2007). “Making A Life or Making A Living?: CrossCultural Comparisons of Business Students Work and Life Values in Canada and France", Cross Cultural Management: An International Journal, 14(3): 174-195.

\section{İNTERNET KAYNAKLARI}

${ }^{1}$ http://www.tdk.gov.tr/index.php?option=com_gts\&arama=gts\&guid=TDK.GTS.59fc36f540d 725.99604901, Erişim Tarihi: 3.11.2017.

${ }^{2}$ https://www.sbeonline.org/about-us/our-history, Erişim Tarihi: 03.11.2017.

${ }^{3}$ http://igiad.com/kurumsal/igiad/tarihce, Erişim Tarihi: 27.10.2017.

${ }^{4}$ http://www.isahlakizirvesi.com, Erişim Tarihi: 27.10.2017. 